\section{DAN RESIKO PENGELOLAANNYA}

Pariwisata mempunyai peranan penting dalam perekonomian Indonesia, baik sebagai sumber penerimaan devisa maupun sebagai sumber kesempatan kerja dan kesempatan berusaha. Bahkan dari potensi pengembangan pariwisata menjadi kegiatan riil dalam perekonomian, akan dapat mengentaskan kemiskinan. Sebagai Daerah Tujuan Wisata (DTW) ke 21, Provinsi Jambi bangkit menawarkan beragam jasa kepariwisataan yang dimiliki, seperti air terjun, goa, hutan mangrove, alam pegunungan/perkebunan, agrowisata karet/ kelapa sawit dan pariwisata percandian yang memiliki nilai historis. Pengembangan Pariwisata dengan jumlah kunjungan wisatawan dipengaruhi oleh berbagai faktor yang memerlukan telaahan penting sebagai dasar penetapan kebijakan agar sasaran pembangun kepariwisataan khususnya dapat diraih dengan tepat guna secara efektif.

Kawasan Cagar Budaya (KCBN) Muarajambi merupakan satusatunya kawasan cagar budaya di Provinsi Jambi yang telah ditetapkan oleh Menteri Pendidikan dan Kebudayaan melalui Surat Keputusan Nomor 259/M/2013 sebagai Kawasan Cagar Budaya Peringkat Nasional. Dalam perkembangan pemanfaatannya, KCBN Muarajambi merupakan objek wisata utama di Kabupaten Muara Jambi yang bertumpu pada cagar budaya. Banyaknya jumlah pengunjung tentu dapat menjadi sumber pendapatan bagi daerah maupun masyarakat sekitar, namun hal ini dapat menjadi hal ini dapat menjadi tantangan untuk mengelolanya dengan baik. Belum adanya manajemen pengunjung seperti alur perjalanan serta pembatasan jumlah pengunjung dikhawatirkan dapat merusak cagar budaya yang dilindungi undangundang. Persoalan sampah dari pengunjung pada saat kegiatan wisata berlangsung selalu menjadi masalah tersendiri dalam upaya pelestarian.

Untuk melindungi dari berbagai risiko, maka digunakan paradigma baru dalam konservasi, yakni prinsip preventif, berupa manajemen risiko. Pendekatan ini bertujuan untuk menemukan strategi penanganan risiko yang tepat, terpadu, dan berkelanjutan sehingga risiko dapat dikelola dan diminimalisasi untuk mempertahankan kualitas cagar budaya dan mensejahterakan masyarakat. Dalam analisis risiko, hasil penilaian risiko diklasifikasikan ke dalam tiga tingkat kelas yaitu risiko rendah, risiko sedang dan risiko tinggi.

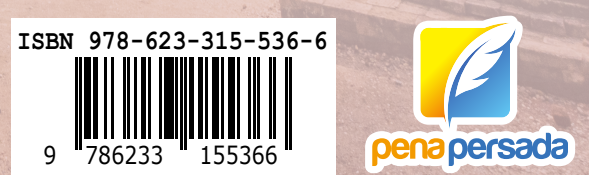

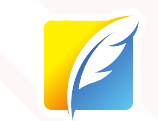

penapersada

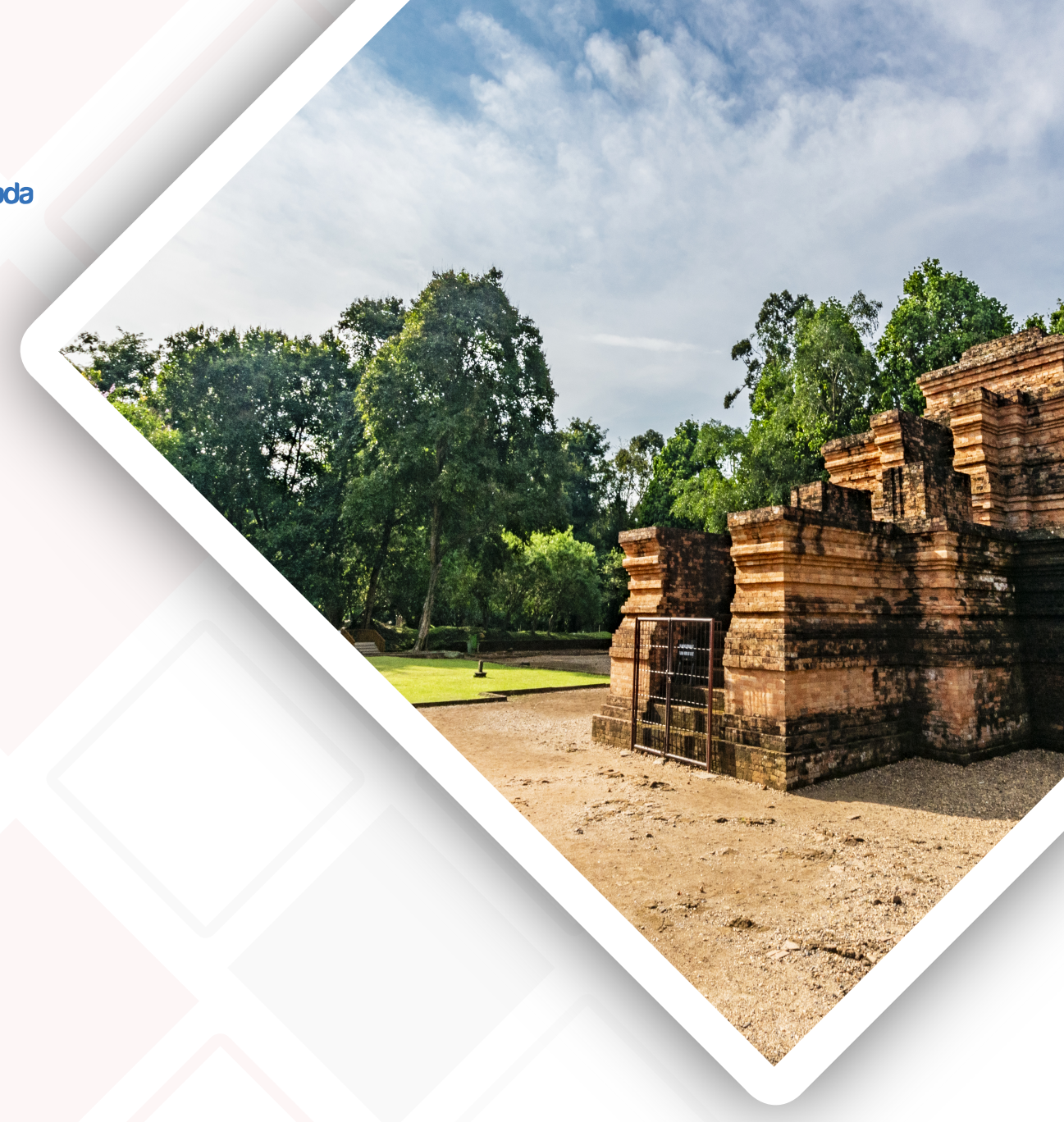

\section{PARIWISATA PERCANDIAN}

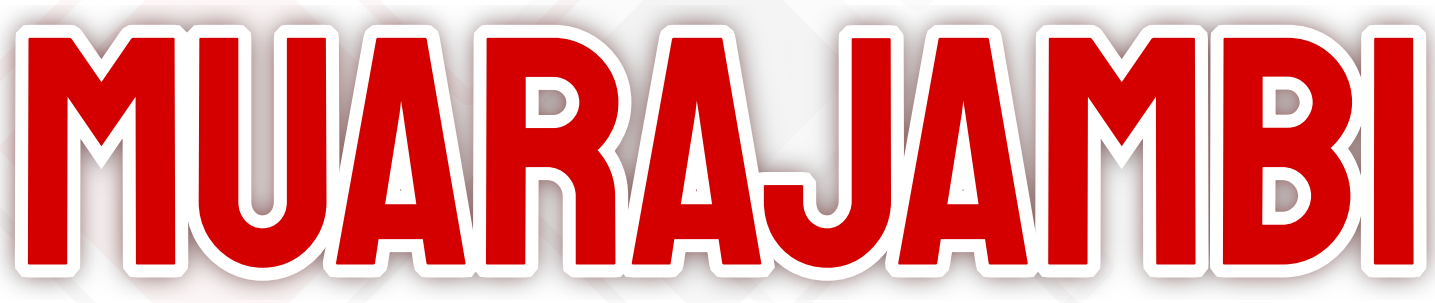

DANRESIKOPENGELOLAANNYA

Muhammad Safri | Christina Novitri Andarsih | Iwan Eka Putra 


\title{
PARIWISATA PERCANDIAN \\ MUARA JAMBI DAN RISIKO PENGELOLAANNYA
}

\author{
MUHAMMAD SAFRI \\ CHRISTINA NOVITRI ANDARSIH \\ IWAN EKA PUTRA
}

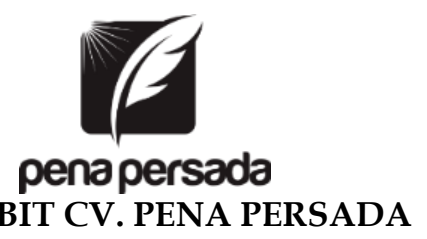




\title{
PARIWISATA PERCANDIAN \\ MUARA JAMBI DAN RISIKO PENGELOLAANNYA
}

\author{
Penulis: \\ Muhammad Safri \\ Christina Novitri Andarsih \\ Iwan Eka Putra \\ ISBN: 978-623-315-536-6 \\ Editor: \\ Wiwit Kurniawan \\ Design Cover: \\ Retnani Nur Briliant \\ Layout: \\ Nisa Falahia
}

\section{Penerbit CV. Pena Persada}

Redaksi:

Jl. Gerilya No. 292 Purwokerto Selatan, Kab. Banyumas Jawa Tengah

Email: penerbit.penapersada@gmail.com Website: penapersada.com Phone: (0281) 7771388

\section{Anggota IKAPI}

All right reserved

Cetakan pertama: 2021

Hak Cipta dilindungi oleh undang-undang. Dilarang memperbanyak karya tulis ini dalam bentuk apapun tanpa izin penerbit 


\section{KATA PENGANTAR}

Segala puji senantiasa kita panjatkan kehadirat Allah Swt, atas segala rahmat dan karunianya, akhirnya penulis dapat menyelesaikan penyusunan buku yang berjudul "PARIWISATA PERCANDIAN MUARA JAMBI DAN RISIKO PENGELOLAANNYA". Saya menyadari bahwa tanpa bantuan dan bimbingan dari berbagai pihak sangatlah sulit bagi saya untuk menyelesaikan karya ini. Kami ucapkan banyak terima kasih pada semua pihak yang telah membantu penyusunan buku ini, sehingga buku ini bisa hadir di hadapan pembaca.

Pariwisata sebagai salah satu komoditi ekspor yang bersifat invisible export merupakan sumber pendapatan daerah. Selain itu kegiatan pariwisata juga memberikan lapangan pekerjaan dalam satu daerah. Artinya, menurut kriteria tertentu maka pariwisata dapat merupakan salah satu faktor basis dalam perekonomian daerah baik dari segi pendapatan maupun kesempatan kerja. Dengan adanya pembangunan kepariwisataan diharapkan akan dapat memberikan manfaat langsung maupun tidak langsung. Dalam buku ini dibahas beberap teori/konsep pariwisata, peranan pariwisata percandian Muara Jambi berdasarkan ukuran pendapatan dan kesempatan kerja menyangkut sumbangan ekonominya terhadap perekonomian regional serta analisis manajemen risiko. Bagian pertama buku ini yang membahas aspek pariwisata dilakukan disaat situs tersebut masih masuk dalam wilayah Kabupaten Dati II Batanghari. Namun ketika tulisan menyangkut manajemen resiko pengelolaan, situs tersebut sudah masuk ke dalam wilayah Kabupaten Muara Jambi yang terpisah dari Kabupaten Batanghari, sehingga beberapa hasil hitungan seperti pendekatan pariwisata wilayah dan sebagainya tetap ditulis Kabupaten Batanghari.

Penulis menyadari bahwa buku ini masih jauh dari kesempurnaan. Oleh karena itu kritik dan saran yang membangun sangat dibutuhkan guna penyempurnaan buku ini. Akhir kata kiranya Allah Swt berkenan membalas segala kebaikan semua pihak yang telah membantu

Penulis 


\section{DAFTAR ISI}

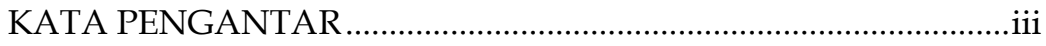

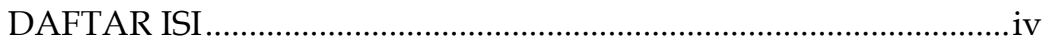

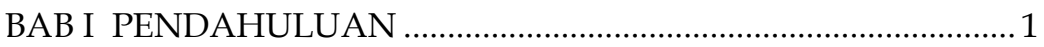

A. Peran Sektor Pariwisata di Provinsi Jambi ........................ 1

B. Pemanfaatan Kawasan Cagar Budaya ................................ 4

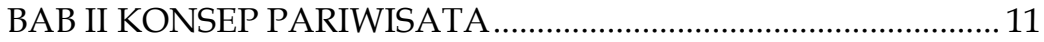

A. Pengertian Pariwisata ...................................................... 11

B. Prasarana dan Sarana Parawisata ...................................... 14

BAB III KONSEP PENDEKATAN PARIWISATA WILAYAH ......16

A. Pendapatan Pariwisata .................................................... 16

B. Pendekatan Model Basis Ekonomi .................................16

C. Pelipatgandaan Pendapatan dan Tenaga Kerja ..............18

BAB IV PERMINTAAN KOMODITI PARIWISATA DAN

PENDEKATAN BIAYA PERJALANAN (TRAVEL

COST APPROACH) ........................................................ 19

A. Permintaan Komoditi Pariwisata......................................19

B. Pendekatan Biaya Perjalanan (Travel Cost Approach).... 20

BAB V PENGARUH PARIWISATA PERCANDIAN MUARA

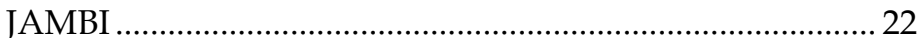

A. Pengaruh Pariwisata Percandian Muara Jambi

Terhadap Pendapatan Masyarakat.................................. 22

B. Pendapatan Sektor Formal dan Informal Pariwisata ... 24

BAB VI GAMBARAN UMUM DAERAH MUARA JAMBI............. 25

A. Keadaan Umum Kabupaten Muara Jambi ...................... 25

B. Penduduk dan Mata Pencaharian .................................. 26

C. Deskripsi Kawasan Cagar Budaya Muarajambi ............27

D. Sejarah Singkat Kompleks Percandian Muara Jambi... 30

1. Candi Koto Mahligai ....................................................... 33

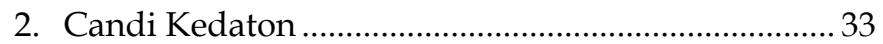

3. Candi Gedong I dan II ............................................. 34

4. Candi Gumpung ............................................................ 35

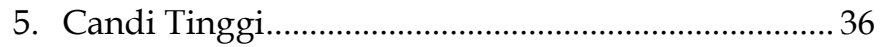

6. Candi Kembar Batu ....................................................... 37

7. Candi Astano.................................................................. 37 


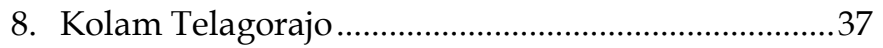

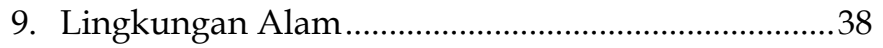

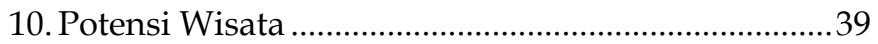

BAB VII ANALISIS DAMPAK PARIWISATA PERCANDIAN

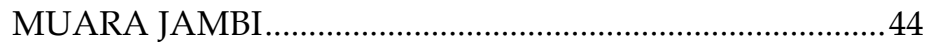

A. Dampak Pariwisata Percandian Muara Jambi

Terhadap Ekonomi Wilayah.............................................4 44

1. Pendekatan Pendapatan ..............................................4 44

2. Pendekatan Tenaga Kerja ..............................................45

3. Proyeksi Tenaga Kerja.................................................46

B. Peranan Pariwisata Percandian Muara Jambi Terhadap Kesejahteraan Masyarakat Sekitarnya...........47

C. Uji Nilai Tengah Pendapatan Responden Sektor Pariwisata dan Non Pariwisata. ....................................50

D. Pendekatan Nilai Kontingensi (Contingen Valuation

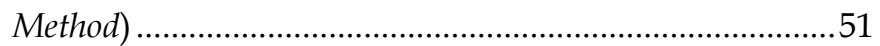

E. Analisis SWOT Pariwisata Percandian Muara Jambi...55 BAB VIII FAKTOR-FAKTOR YANG MEMPENGARUHI JUMLAH KUNJUNGAN WISATAWAN .............................57

A. Analisis Faktor-Faktor yang Mempengaruhi Jumlah Kunjungan Wisatawan Nusantara ..................................57

B. Analisis Faktor-faktor yang Mempengaruhi Jumlah Kunjungan Wisatawan Mancanegara

BAB IX PEMANFAATAN WARISAN BUDAYA …………..............68

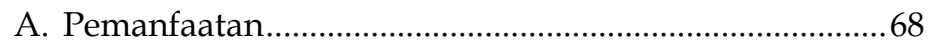

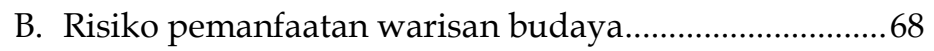

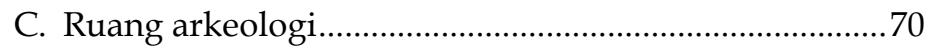

D. Zonasi cagar budaya …………………………................ 72

E. Penggunaan lahan ..............................................................

BAB X REGULASI DAN MANAJEMEN RISIKO …………….........75

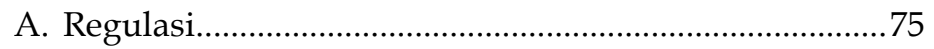

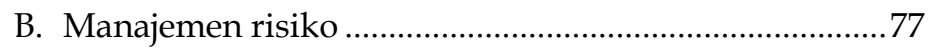

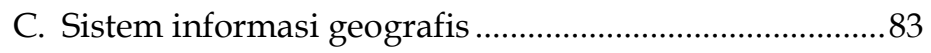


BAB XI IDENTIFIKASI ANCAMAN, KERENTANAN, DAN

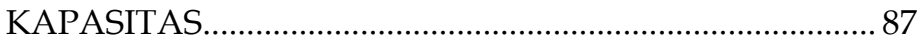

A. Ancaman .......................................................................... 88

1. Ketidaksesuaian Penggunaan Lahan ........................8 88

2. Arahan fungsi ruang Rencana Tata Ruang Wilayah Kabupaten Muara Jambi......................... 110

3. Vandalisme dan tekanan pengunjung................... 113

B. Kerentanan .................................................................... 121

1. Kerentanan Fisik ................................................... 121

2. Status kepemilikan lahan ...................................... 131

3. Kerentanan pemangku kepentingan .................... 132

C. Kapasitas ................................................................... 135

BAB XII PENGELOLAAN RISIKO PEMANFAATAN RUANG

KCBN MUARAJAMBI ..................................................... 140

A. Nilai Penting KCBN Muarajambi .............................. 140

B. Pengelolaan risiko pemanfaatan ruang $\mathrm{KCBN}$

Muarajambi ............................................................... 145

C. Analisis ancaman, kerentanan, dan kapasitas pada penilaian risiko pemanfaatan ruang $\mathrm{KCBN}$ Muarajambi ............................................................. 174

D. Analisis kelas risiko ................................................. 181

E. Analisis pengelolaan risiko........................................ 182

BAB XIII PENUTUP .................................................................... 188

DAFTAR PUSTAKA …............................................................... 191

TENTANG PENULIS .................................................................... 205 


\section{BAB I \\ PENDAHULUAN}

\section{A. Peran Sektor Pariwisata di Provinsi Jambi}

Pariwisata mempunyai peranan penting dalam perekonomian Indonesia, baik sebagai sumber penerimaan devisa maupun sebagai sumber kesempatan kerja dan kesempatan berusaha. Bahkan dari potensi pengembangan pariwisata menjadi kegiatan riil dalam perekonomian, akan dapat mengentaskan kemiskinan.

Di dalam GBHN disebutkan, bahwa pembangunan kepariwisataan perlu dilanjutkan dan ditingkatkan dengan mengembangkan dan mendayagunakan sumber dan potensi yang dapat diandalkan. Sejak 1991, pemerintah telah menetapkan Daerah Tujuan Wisata (DTW) dan Tahun Kunjungan Wisata Indonesia.

Paket deregulasi bidang usaha kepariwisataan juga ditempuh oleh pemerintah, seperti penyederhanaan izin mendirikan hotel dari beberapa macam izin menjadi dua izin, yaitu meliputi izin tetap dan izin sementara. Implikasi kebijaksanaan tersebut adalah meningkatnya investasi di bidang perhotelan.

Dari tahun 1989 sampai dengan tahun 1992, jumlah akomodasi hotel bintang dan non bintang di Indonesia rata-rata mengalami peningkatan 10.60\%. Jika tahun 1989 jumlah akomodasi sebanyak 6125 unit, maka untuk tahun 1992 meningkat menjadi 7.492 unit. Begitu pula dengan jumlah kamar akomodasi dan tempat tidur pada selang periode yang sama masing-masing mengalami peningkatan $14.35 \%$ dan $14.52 \%$ rata-rata per tahun. Tahun 1992 jumlah kamar akomodasi sebanyak 160.366 unit, sedangkan tempat tidur berjumlah 292.046 unit.

Untuk lingkup propinsi Jambi, jumlah akomodasi kamar hotel dan tempat tidur hotel pada tahun 1992, masing-masing tercatat sebanyak 86 unit, 1.677 dan 3.297 unit. Kalau jumlah 
akomodasi dan tempat tidur periode 1989-1992 hanya mengalami peningkatan $2.44 \%$ dan $5.78 \%$, maka jumlah kamar hotel pada periode sama meningkat jauh lebih besar, yakni rata-rata $24.31 \%$ per tahun. Dengan demikian peningkatan jumlah wisatawan nusantara (Wisnu) yang datang ke Indonesia seperti tersebut di atas telah diimbangi oleh peningkatan jumlah kamar hotel yang jauh lebih tinggi. Akibatnya tingkat hunian hotel pada periode tersebut cenderung turun sekitar 0.70\% untuk kondisi nasional dan 13.88\% untuk Provinsi Jambi.

Pembenahan sisi supply kepariwisataan terus berlanjut. Dengan tujuan agar wisatawan aktual dan wisatawan potensial lebih banyak terjaring untuk meningkatkan kunjungan mereka. Berbagai kegiatan promosi pariwisata juga dilakukan hingga ke luar negeri.

Sebagai Daerah Tujuan Wisata (DTW) ke 21, Provinsi Jambi bangkit menawarkan beragam jasa kepariwisataan yang dimiliki, seperti air terjun, goa, hutan mangrove, alam pegunungan/perkebunan, agrowisata karet/kelapa sawit dan pariwisata percandian yang memiliki nilai historis.

Kecenderungan peningkatan arus kunjungan wisatawan diharapkan akan dapat memberi warna tersendiri bagi pembangunan ekonomi Kabupaten Batang Hari pada umumnya dan kepada masyarakat sekitar percandian khususnya.

Kompleks percandian Muara Jambi yang berada di Kecamatan Sekernan Kabupaten Dati II Batang Hari Provinsi Jambi berisi 8 buah percandian dan sebuah kolom kuno peninggalan kerajaan Melayu Kuno yang erat hubungannya dengan zaman kejayaan kerajaan Hindu di Pulau Jawa. Di sekitar kompleks percandian Muara Jambi ini, disamping banyak terdapat perkebunan budidaya penduduk seperti durian dan lain-lain, lokasinya terletak di pinggir Sungai Batanghari dan melalui transportasi darat mudah dijangkau, oleh karena telah dibangun prasarana jalan aspal oleh pemerintah baik dari dan ke Kotamadya dengan jarak terdekat, maupun ruas jalan yang berada dari dan ke kabupaten lain 
yang berbatasan dengan Kabupaten Dati II Batang Hari seperti Kabupaten Tanjung Jabung. Aksesibilitas jalur lintas Timur ke Propinsi Riau jalan aspal dengan ruas jalan ke percandianpun di nilai positif akibat konstruksi permukaan jalan aspal yang mulus.

Untuk mendukung agar lebih banyak wisatawan yang datang ke lokasi percandian Muara Jambi, baru-baru ini Pemerintah Daerah Tingkat II Kabupaten Batang Hari telah meresmikan beroperasinya satu buah kapal yang melayari rute Kotamadya Jambi-kompleks percandian Muara Jambi. Ratarata waktu tempuh 3 jam Peresmian beroperasinya kapal dilakukan oleh Menparpostel pada awal 1995.

Penurunan prosentase daya tarik wisatawan di Indonesia terhadap percandian menjadi $1.8 \%$ pada tahun 1988 dari $12.2 \%$ tahun 1984/198, menjadi tantangan bagi unsur-unsur yang terlibat dalam kepariwisataan.

Peningkatan berbagai sarana dan prasarana dan dampaknya terhadap peningkatan kesempatan kerja, adalah konsekuensi logis dari peningkatan jumlah kunjungan wisatawan (Hari Hartono, 1974).

Walaupun berbagai pembenahan telah dilakukan oleh pemerintah daerah bersama masyarakat untuk meningkatkan objek pariwisata percandian tersebut, namun dirasa masih terdapat upaya-upaya lain yang kurang/belum mendukung dilakukan mengingat adanya berbagai keterbatasan. Untuk itu berbagai faktor yang mempengaruhi jumlah kunjungan wisatawan ke percandian Muara Jambi perlu dipakai sebagai pondasi penting dalam perencanaan penawaran komoditi pariwisata dimaksud. Sejalan dengan hal demikian, pengkajian peranan pariwisata percandian Muara Jambi terhadap pengembangan ekonomi wilayah Kabupaten Batang Hari perlu dilakukan guna mengetahui bagaimana dampaknya terhadap tingkat kesejahteraan dan tingkat pendapatan masyarakat disekitarnya. 
Pariwisata sebagai salah satu komoditi ekspor yang bersifat invisible export merupakan sumber pendapatan daerah. Selain itu kegiatan pariwisata juga memberikan lapangan pekerjaan dalam satu daerah. Artinya, menurut kriteria tertentu maka pariwisata dapat merupakan salah satu faktor basis dalam perekonomian daerah baik dari segi pendapatan maupun kesempatan kerja.

Paling tidak, dengan adanya pembangunan kepariwisataan diharapkan akan dapat memberikan manfaat langsung maupun tidak langsung, baik terhadap pemerintah dalam bentuk penerimaan daerah maupun terhadap masyarakat sekitar lokasi percandian Muara Jambi berada, seperti: terhadap pendapatan dan kesempatan kerja yang pada gilirannya secara bersama-sama berfungsi menunjang pengembangan wilayah Kabupaten Kabupaten Muara Jambi.

Atas dasar pertimbangan seperti tersebut di atas, penulis ingin mengetahui lebih jauh dampak pembangunan dan pengembangan pariwisata percandian Muara Jambi terhadap ekonomi wilayah Kabupaten Batang Hari, masyarakat sekitarnya serta faktor-faktor permintaan apa saja yang berhubungan erat dengan upaya untuk meningkatkan jumlah kunjungan wisatawan ke lokasi pariwisata percandian tersebut.

\section{B. Pemanfaatan Kawasan Cagar Budaya}

Kawasan Cagar Budaya (KCBN) Muarajambi merupakan satu-satunya kawasan cagar budaya di Provinsi Jambi yang telah ditetapkan oleh Menteri Pendidikan dan Kebudayaan melalui Surat Keputusan Nomor 259/M/2013 sebagai Kawasan Cagar Budaya Peringkat Nasional. Kawasan tersebut merupakan cagar budaya yang dilindungi oleh UndangUndang Republik Indonesia Nomor 11 Tahun 2010 tentang Cagar Budaya. Kawasan ini memiliki nilai penting bagi ilmu pengetahuan, sejarah, pendidikan, agama, dan kebudayaan sehingga perlu dilestarikan keberadaannya. Kawasan Cagar Budaya Muarajambi telah masuk dalam daftar nominasi sementara (tentative list) warisan dunia dengan nomor Ref. 5465 
melalui World Heritage Comitee (WHC) (https://whc.unesco.org /en/tentativelists/5465/).

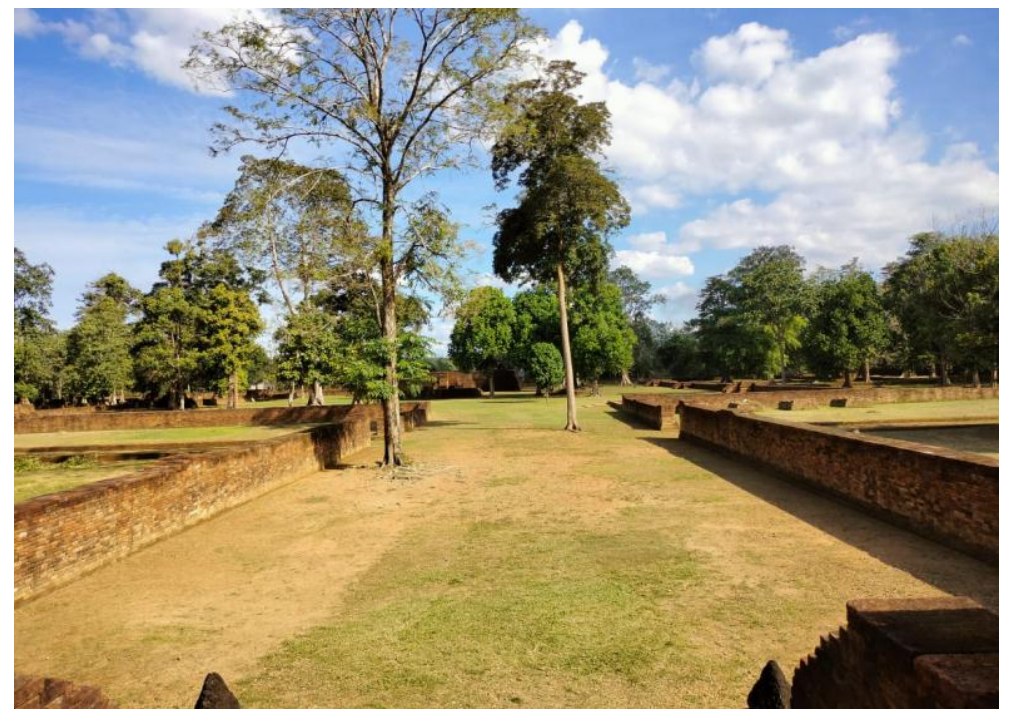

Gambar 1. 1 Kawasan Cagar Budaya Muarajambi

KCBN Muarajambi berada di 2 (dua) kecamatan yakni Kecamatan Maro Sebo dan Kecamatan Taman Rajo, Kabupaten Muara Jambi. Deretan candi berbahan bata berada pada tanggul alam lama Sungai Batanghari, sementara lingkungan berupa rawa belakang (back swamp) dan dataran banjir. Terdapat kanal-kanal buatan yang dihubungkan dengan sungai-sungai alam yang bermuara di Sungai Batanghari. Keberadaan kanal merupakan satu kesatuan yang tidak dapat terpisahkan dengan candi-candi di Muarajambi yang tercipta berasal dan dilandasi oleh konsep permukiman ideal pada masanya. Selain itu juga terkait dengan konsepsi tentang kosmologis yang dianut dalam kepercayaan Budhisme (Widiatmoko, 2009: 1). Berdasarkan penelitian tim Pemetaan Terintegrasi Kepurbakalaan Sriwijaya pada tahun 1985, dari data pengeboran tanah di daerah antara Candi Tinggi dan Candi Astano yang dilakukan pada kedalaman $15 \mathrm{~cm}$ hingga 60 $\mathrm{cm}$ menunjukkan terdapatnya lapisan budaya yang ditandai dengan penemuan tanah lempung coklat yang banyak 
mengandung kereweng keramik dan pecahan bata (Sutikno, 1985: IV.2-IV.23). Oleh sebab itu lapisan tanah permukaan di KCBN Muarajambi sangat potensial terhadap temuan tinggalan arkeologi.

Luas area yang ditetapkan sebagai kawasan cagar budaya adalah 3981 ha. Lahan yang merupakan aset Balai Pelestarian Cagar Budaya (BPCB) Jambi hingga tahun 2019 adalah 28,6855 ha, meliputi beberapa lokasi candi dan menapo, serta jalan penghubung antarsitus dan lokasi rencana pembangunan gedung koleksi arkeologi oleh Balai Pelestarian Cagar Budaya Jambi. Sementara penguasaan lahan lainnya adalah Pemerintah Kabupaten Muara Jambi dan perorangan, baik masyarakat setempat maupun pemilik modal yang berasal dari luar desa. Sebagian pemilik lahan telah memiliki sertifikat, namun sebagian besar lainnya hanya memiliki surat pernyataan penguasaan fisik bidang tanah (sporadik).

Dalam perkembangan pemanfaatannya, KCBN Muarajambi merupakan objek wisata utama di Kabupaten Muara Jambi yang bertumpu pada cagar budaya. Dalam Peta Pola Ruang Rencana Tata Ruang Wilayah Kabupaten Muara Jambi, wilayah KCBN Muarajambi seluas hampir 1650 ha diperuntukan sebagai Kawasan Wisata Candi.

Pada prinsipnya, semua aktivitas pariwisata mengarah pada perubahan lingkungan dan sosial (Padersen, 2002: 30). Perubahan lingkungan dalam hal ini tidak saja mempengaruhi ekologi yang menjadi tempat berlangsungnya kegiatan pemanfaatan akan termasuk juga cagar budaya dan wujudwujud ekspresi budaya yang ada. Kunjungan wisatawan terus mengalami peningkatan, khususnya pada waktu-waktu tertentu pada hari libur seperti hari raya dan tahun baru diprediksi menimbulkan dampak merugikan apabila tidak dikelola dengan baik. Pada masa liburan Idul Fitri tahun 2019 yakni tanggal 1 sampai dengan 9 Juni 2019 pengunjung di KCBN Muarajambi mencapai 26.467 jiwa. Banyaknya jumlah pengunjung tentu dapat menjadi sumber pendapatan bagi daerah maupun masyarakat sekitar, namun hal ini dapat 
menjadi hal ini dapat menjadi tantangan untuk mengelolanya dengan baik. Belum adanya manajemen pengunjung seperti alur perjalanan serta pembatasan jumlah pengunjung dikhawatirkan dapat merusak cagar budaya yang dilindungi undang-undang. Persoalan sampah dari pengunjung pada saat kegiatan wisata berlangsung selalu menjadi masalah tersendiri dalam upaya pelestarian (David, 2019: 5-19).

Pemanfaatan lahan lainnya yang telah berlangsung dari sebelum dikeluarkannya penetapan kawasan cagar budaya peringkat nasional oleh Menteri Pendidikan dan Kebudayaan pada tahun 2013 dan terus berkembang hingga saat ini adalah pemanfaatan sebagai lokasi industri. Lokasi penimbunan (stockpile) batu bara dan cangkang buah kelapa sawit serta pabrik pengolahan minyak sawit berada dekat dengan Sungai Batanghari sebagai jalur transportasi utama menuju ke laut. Perkembangan industri berdampak positif bagi pendapatan asli daerah dan ekonomi beberapa masyarakat yang terlibat dalam aktivitas industri, namun aktivitas industri juga memunculkan ragam dampak negatif bagi cagar budaya dan lingkungan sekitarnya.

Kegiatan penimbunan batu bara berdampak menurunkan kualitas udara, tingkat kebisingan, dan kualitas badan air (Hartono, 2015: 103). Debu batu bara yang terbawa angin diketahui mencapai struktur candi di komplek Candi Gumpung, selain itu juga mencemari badan sungai. Aktivitas industri berupa pelayaran di Sungai Batanghari menjadi salah satu faktor penyebab erosi dinding sungai selain dipengaruhi oleh perkembangan meander sungai. Erosi terjadi akibat adanya gelombang yang mengikis dinding sungai pada saat kapal tongkang dan pompong melintasi kawasan. Erosi yang terjadi telah memberikan dampak pada pemukiman masyarakat, jalan, serta jatuhnya bagian bangunan candi ke badan Sungai Batanghari. Terdapat dua struktur candi yang diidentifikasi telah terkikis oleh aliran Sungai Batanghari, yakni struktur bata di halaman kantor PT. Gaya Wahana Timber yang 
sudah terjadi pada tahun 1984 (Mundardjito, 1986: 13) dan Candi Dusun Mudo yang sudah berlangsung sejak tahun 2010.

Di dalam KCBN Muarajambi terdapat 8 (delapan) desa pada dua kecamatan yang seluruhnya termasuk ke dalam Kabupaten Muara Jambi. Terdapat kebutuhan ruang untuk permukiman dan pertanian bagi penduduk di dalam kawasan. Pembukaan lahan secara luas terjadi akibat alih kepemilikan melalui proses jual beli dengan orang dari luar desa tersebut yang memanfaatkan sebagai perkebunan kelapa sawit. Alih fungsi lahan dalam arti perubahan penggunaan lahan, pada dasarnya tidak dapat dihindarkan dalam proses pembangunan (Lisdiyono, 2004 dalam Ajimas, 2017: 1). Pertumbuhan penduduk serta bertambah banyaknya tuntutan kebutuhan masyarakat akan lahan, seringkali mengakibatkan timbulnya benturan kepentingan atas penggunaan sebidang lahan. Akibatnya penggunaan lahan menjadi tidak sesuai dengan peruntukannya (Khadiyanto, 2005: 35). Hal ini dapat memunculkan potensi konflik dalam pemanfaatan ruang serta terjadinya degradasi lahan.

Pengaturan ruang kawasan dalam rangka pelestarian cagar budaya dengan zonasi cagar budaya telah dibuat berdasarkan kajian zonasi KCBN Muarajambi. Sebelumnya telah dilakukan beberapa kali penyusunan masterplan KCBN Muarajambi, yakni pada tahun 1988/1999, 2004, 2006, dan 2014. Peraturan Daerah tentang Rencana Tata Ruang Wilayah baik Provinsi Jambi maupun Kabupaten Muara Jambi belum sepenuhnya mendukung pemanfaatan ruang yang sesuai dengan karakter situs di KCBN Muarajambi.

Beberapa upaya pelindungan terhadap cagar budaya diantaranya penyusunan pemintakatan kawasan tersebut yang berdasarkan ketentuan Undang-Undang Nomor 5 Tahun 1992 tentang Benda Cagar Budaya dan kajian zonasi yang mengacu kepada Undang-Undang Nomor 11 Tahun 2010 tentang Cagar Budaya. Kajian zonasi tahun 2017 sampai dengan tahun 2019 sepenuhnya mengacu Undang-Undang Nomor 11 Tahun 2010 dan masih berproses hingga sekarang. Penentuan zonasi di 
dalam KCBN Muarajambi memerlukan waktu yang panjang, hal ini dipengaruhi banyaknya pemangku kepentingan (stakeholders) yang berkepentingan dalam pemanfaatan ruang di dalam kawasan. Pada tahun 2019 telah dilaksanakan dua kali diskusi kelompok terpumpun yang dihadiri unsur Pemerintah Daerah, Tim Ahli Cagar Budaya Nasional, Direktorat Pelindungan Cagar Budaya dan Permuseuman, BPCB Provinsi Jambi, Kepala Desa, Camat, dan unsur masyarakat yakni pada tanggal 14 Mei 2019 dan 28 Agustus 2019. Berdasarkan hasil kajian tersebut zonasi di KCBN Muarajambi dibagi menjadi 4 (empat), yaitu zona inti, zona penyangga, zona pengembangan, dan zona penunjang sesuai ketentuan peraturan perundangan.

Cagar budaya di dalam KCBN Muarajambi menjadi bukti masa lalu yang tak tergantikan untuk mendukung pembangunan sosial, budaya, pendidikan, dan ilmu pengetahuan ke masa depan sehingga penting untuk dipertahankan keberadaannya. Cagar budaya ini erat hubungannya dengan identitas budaya dan sejarah keberadaan bangsa Indonesia yang sudah berlangsung ratusan tahun lamanya, dan akan terus berkembang. Diperlukan sistem manajemen yang baik guna mempertahankan keberadaan cagar budaya di KCBN Muarajambi dari berbagai faktor risiko pada pemanfaatan ruangnya. Sistem manajemen yang sesuai adalah dengan manajemen risiko cagar budaya. Manajemen risiko ini menawarkan pandangan yang lebih holistik dan terintegrasi dengan berbagai dimensi sumber daya budaya yang saling berkaitan antar elemen, yaitu cagar budaya, stakeholder, dan ekologi. Dengan melihat hubungan elemen tersebut, maka risiko sumber daya budaya dapat mencakup satu atau seluruh elemen berisiko, termasuk ancaman authenticity, integritas, dan sustainability sumber daya budaya (Jigyasu, 2005: 144). Daya upaya dalam menjaga berlanjutnya nilai serta objek cagar budaya KCBN Muarajambi supaya dapat terus dirasakan dan dinikmati manfaatnya oleh generasi berikutnya akan menjadi fokus dalam pengelolaan risiko pada pembahasan ini. 
Berdasarkan berbagai ancaman serta permasalahan yang terjadi di KCBN Muarajambi di atas, implementasi manajemen risiko dalam konservasi Kawasan Cagar Budaya merupakan kebutuhan yang mendesak. Hal ini mengingat pemanfaatan cagar budaya memiliki risiko baik terhadap obyek cagar budaya, kehidupan masyarakat, lingkungan, maupun sigifikansinya. Untuk melindungi dari berbagai risiko, maka digunakan paradigma baru dalam konservasi, yakni prinsip preventif, berupa manajemen risiko. Pendekatan ini bertujuan untuk menemukan strategi penanganan risiko yang tepat, terpadu, dan berkelanjutan sehingga risiko dapat dikelola dan diminimalisasi untuk mempertahankan kualitas cagar budaya dan mensejahterakan masyarakat (Dewi, 2015: 4). Dalam analisis risiko, hasil penilaian risiko diklasifikasikan ke dalam tiga tingkat kelas yaitu risiko rendah, risiko sedang dan risiko tinggi (BNPB, 2012: 47).

Dalam mengimplementasikan manajemen risiko di KCBN Muarajambi, masing-masing stakeholder perlu memahami tugas dan fungsinya dalam pelestarian cagar budaya sesuai dengan Undang-Undang Republik Indonesia Nomor 11 Tahun 2010. 


\section{BAB II \\ KONSEP PARIWISATA}

\section{A. Pengertian Pariwisata}

Pasal 5 Resolusi Dewan Ekonomi dan Sosial PBB (Perserikatan Bangsa-Bangsa) Nomor 870 Tahun 1963, merumuskan wisatawan sebagai pengunjung sementara yang paling sedikit tinggal selama 24 jam di negara yang dikunjunginya, dan tujuan perjalanannya dapat digolongkan :

1. Pesiar, seperti untuk keperluan rekreasi, liburan, kesehatan, studi keagamaan dan olahraga.

2. Hubungan dagang, keluarga, konverensi dan misi keagamaan.

Batasan tersebut telah diterima oleh Komisariat Statistik PBB, sebagai batasan yang berlaku untuk wisatawan internasional.

Wisatawan adalah individu atau kelompok individu yang mempertimbangkan dan merencanakan tenaga beli yang dimilikinya untuk perjalanan rekreasi, berlibur, yang tertarik pada perjalanan pada umumnya, mengikuti perjalanan yang mereka lakukan, menambah pengetahuan, tertarik oleh pelayanan yang diberikan oleh suatu tujuan wisata yang dapat menarik pengunjung di masa yang akan datang (Marhaini, 1992).

Di dalam GBHN 1993, pengertian pariwisata dikatakan sebagai suatu perjalanan yang dilakukan untuk sementara waktu yang diselenggarakan dari suatu tempat ke tempat lain dengan maksud bukan untuk berusaha (bisnis) atau mencari nafkah di tempat yang dikunjunginya, tetapi semata-mata untuk menikmati perjalanan tersebut guna pertamasyaan atau rekreasi untuk memenuhi kebutuhan yang beraneka ragam.

Lebih jauh untuk pengembangan dan pembinaan kepariwisataan di Indonesia, menurut Instruksi Presiden Nomor 9 Tahun 1969 disebutkan bahwa wisatawan adalah 
setiap orang yang berpergian dari tempat tinggalnya untuk berkunjung ke tempat lain untuk menikmati perjalanan dan kunjungan itu.

Dengan demikian, batasan wisatawan dalam negeri maupun asing adalah :

1. Perjalanan itu dilakukan lebih dari 24 jam.

2. Perjalanannya itu dilakukannya hanya untuk sementara waktu.

3. Orang yang melakukannya tidak mencari nafkah di tempat atau negara yang dikunjunginya.

Menurut Spillane (1993), terdapat beberapa keuntungan dan kerugian industri pariwisata.

\section{Keuntungan Industri Pariwisata:}

a. Memberi kontribusi terhadap pendapatan masyarakat dan memperbaiki neraca pembayaran (balance of payment).

b. Meningkatkan pendapatan masyarakat.

c. Menciptakan lapangan kerja.

d. Memperbaiki struktur ekonomi karena berkembangnya sektor ekonomi tersier.

e. Meningkatkan sektor entrepreneur.

\section{Kerugian Industri Pariwisata:}

a. Adanya ketergantungan berkelebihan (over dependent) kepada wisatawan.

b. Mendorong laju inflasi dan nilai lahan (property value) menjadi meningkat.

c. Meningkatkan import karena banyaknya barang untuk infrastruktur pariwisata.

d. Sifat produksinya musiman (seasonal) dan secara umum pengembalian hasil investasi (return on investment) rendah.

e. Bisa menimbulkan external sosial cost lain, misalnya penyakit aids, penetrasi budaya luar. 
Uang yang dibelanjakan wisatawan akan mengalami pembelanjaan kembali. Kondisi ini akan membawa pengaruh adanya efek pengganda (multplier effect), baik terhadap wilayah maupun masyarakat setempat. Untuk itu, pendekatan analisis mengacu pada model ekonomi basis.

Menurut Anwar (1994), pariwisata sama halnya dengan public good lain seperti udara, taman, jalan dan lain-lain, yang menurut sifatnya dapat diidentifikasikan sebagai private good atau public good yang mempunyai sifat berikut ini:

1. Konsumsi yang non-rival atau non-substractable.

2. Konsumsi yang non-excludable atau non-divisible.

Public good dapat dibagi ke dalam pure public good dan mixed good atau quasi public good yang dibedakan atas dasar derajat kekuatan dari sifatnya

Tabel 1. Taksonomi barang-barang dan jasa-jasa

\begin{tabular}{|c|c|c|}
\hline & excludable & non-excludable \\
\hline Rival & $A$ & B \\
\hline Non rival & C & D \\
\hline
\end{tabular}

Golongan A adalah pure private good, misalnya pakaian. Golongan B disebut mixed good yang berbentuk sumber bersama atau common resources, seperti pancoran air untuk umum, hutan komunal. Sedangkan golongan C seperti jalan atau jembatan tol yang bersifat exludable dimana kenikmatan orang tidak akan berkurang karena adanya pemakaian, namun juga bersifat non-rival dimana orang yang tidak membayar dapat dikeluarkan. Pariwisata dapat dimasukkan ke dalam golongan ini.

Golongan D disebut pure public good, seperti udara, air, hutan lindung dan Iain-lain yang kelestariannya dijaga oleh pemerintah dan pemamfaatannya gratis. 